\title{
EFL Instructors' Performance Evaluation at University Level: Prescriptive and Collaborative Approaches
}

\author{
Thaer Issa Tawalbeh \\ English Language Center, Taif University, Taif, Kingdom of Saudi Arabia
}

\begin{abstract}
The present paper aims to investigate EFL instructors' performance at university level according to prescriptive and collaborative approaches in supervision. In order to achieve this target, the researcher addressed three questions. The first investigates instructors' level of performance. The second and third questions aimed to identify instructors' points of strength and action points. In this regard, the researcher developed an observation checklist (Appendix A) for supervisors to use when observing teachers'. He also developed observation guidelines for supervisors to make sure they are following the collaborative approach of supervision (Appendix B). The data were analyzed using descriptive statistics, including means, standard deviation and percentages to answer the first question. To answer the second and third questions, the researcher used content analysis to synthesize the supervisors' feedback given to instructors regarding their points of strengths and action points. The results showed that the instructors' performance was either satisfactory or outstanding based on the supervisors' observation, which could be due to the professional development program conducted to develop their teaching competencies. In addition, the instructors showed themselves competent in other areas related to motivating students and providing them with constructive feedback. However, some instructors still need to develop their competencies in areas such as classroom management and teacher talk time. These have been summarized according to their frequency of occurrence in tables 2 and 3. Based on the results, the researcher drew a number of conclusions and recommendations.
\end{abstract}

Index Terms -instructors' performance, prescriptive approach, collaborative approach, university level

\section{INTRODUCTION AND THEORETICAL BACKGROUND}

\section{A. An Overview of Teacher Quality and Development}

It can be claimed that one of the main roles of teachers is to provide learners with better learning opportunities. In order to help them achieve this target, they need professional development, support and encouragement. Teacher quality is the most important factor affecting student achievement, and students may benefit the most from learning with very effective teachers (Looney, 2011; Motoko et al., 2007; Nye et al., 2004). In this regard, evaluating teachers' performance along with professional development can contribute to developing the quality of teaching which could have a positive effect on student achievement (Looney, 2011; OECDa (2009a).

Developing teachers' quality at Taif University English Language Center is a policy priority. It is vital to continuously update instructors' knowledge and skills, which would positively reflect on their teaching and learning in order to better meet students' needs and interests. In the same direction, teachers are evaluated to identify their needs, and provide them with support and frequent opportunities of professional learning and development.

Looney (2011) summarized the competences of teacher quality. He pointed out that effective teachers have good intellectual skills and good knowledge of the subject area; have rapport with students, recognize the significant role of motivation in learning; have strong classroom management skills; skilled assessors; and work collaboratively with their peers to develop a positive learning climate.

According to Gujjar, Ramzan, \& Bajwa (2011), the qualities used to evaluate teachers include course objectives, using the textbook and supplementary materials, methodology, and content mastery, teacher's use of voice, discipline and motivation. Taylor \& Tyler (2011) stated that teachers are evaluated on specific skills and practices covering classroom management, instruction, content knowledge, and planning.

\section{B. Performance Evaluation}

Teachers need to receive feedback on their performance, which is very crucial for their professional development. Teachers' performance evaluation is meant for a number of purposes. It can be for assessing their performance for further action of promoting them or giving sanctions. Meanwhile, it can be for the purposes of appraisal or identifying their needs for professional development. Kocak (2006) stated that performance evaluation is a process of measurement and appraisal of employees' individual achievements and behaviors. According to him, providing employees of educational institutions with feedback is motivating. In this regard, measuring their performance in a valid and reliable way is very important in providing teachers with feedback on their performance. 
Hanushek and Rivkin (2010) pointed out that performance evaluation is important for American public school teachers and their employers. In recent years, reform efforts in American education have given a priority to evaluating teacher effectiveness. The emphasis on teachers' performance evaluation is enhanced by teacher productivity as long as it is directly related to their ability to promote student achievement.

Some researchers believe that teacher evaluation could improve teachers' performance, taking into consideration incentives based on evaluation and the contribution made by professional development in enhancing teachers' competencies. (Donaldson 2009 \& Weisburg et al. 2009). Randall and Thornton (2001) stated that assessing teachers' performance may cause problems for both teachers and trainers as teachers do not like the idea of being assessed and criticized. In response to this, non- judgmental and humanistic approaches emerged. They maintained that the supervisor might be misunderstood if there is a report at the end of a certain visit. This is likely to happen no matter how the supervisor is supportive. Thus, the supervisor needs to make it clear to the teacher that there exist conflicting roles of the supervisor and will need to separate them.

In this regard, a team of EFL specialists developed a checklist (Appendix A) which includes a set of standards to use when conducting a classroom observation meant to describe the instructors' performance and provide them with feedback on their performance. They have it clear in their minds and should be conveyed to the teacher that the main goal is to support and encourage teachers to reflect on their teaching practices and assist them in their professional development endeavors. The observation has nothing to do with criticism or sanctions. Based on the evaluation, the observer and the teacher meet to discuss the teaching previously conducted for further action of support and development. The observation process conducted is based on a set of observation guidelines for observers to follow to assist observers implement unified practices when conducting classroom observation (Appendix B).

\section{Supervisors and Supervisory Approaches}

A supervisor is someone who has the duty of monitoring and improving the quality of teaching in a given educational situation. This may include inspectors, teacher trainers, educators, tutors, heads of departments, and curriculum specialists. The focus is on face to face interaction between a supervisor and a teacher with reference to classroom teaching previously observed in order to discuss teaching for the purpose of the teacher's professional development (Wallace, 1991). In the context of this study, the term will refer to teacher trainers who have been certified as Train the Trainers based on a certificate they have been awarded by an international organization.

The main goal of observation is to reach a mutual agreement between the supervisor and the teacher on employing better teaching methodologies. The supervisor listens to the teacher and then suggests solutions. Accordingly, the supervisor encourages teachers to employ alternative methods to improve the teaching quality (Widodo \& Zakaria, 2008).

According to Wallace (1991), there are two approaches for supervision to follow with teachers. These are the prescriptive and the collaborative. In the prescriptive, the supervisor is the authority and the source of expertise who judges teachers' performance. On the other hand, in the collaborative approach, the supervisor is a colleague who shares expertise with the teacher. The main aim of this approach is to allow the teacher to reflect upon his own teaching for the purpose of professional development. So, the supervisor attempts to listen to the teacher carefully and help him/her take independent decisions. In this case, supervisors have an important role in improving the teacher's performance. Some supervisors may use characteristics of both approaches using the prescriptive approach with less experienced teachers and the collaborative one with the experienced teachers.

In a similar direction to the approaches of prescriptive and collaborative, researchers suggested summative and formative assessment for teachers' performance. Some suggested separating the two roles of summative and formative assessment (Peterson, 2000; Cleveland et al. 1989). Peterson (2000) suggested two basic arguments made for separation. First, as the formative assessment has no summative consequences, teachers would reduce their defensiveness, they would show their weakness honestly and set challenging goals for their own development. In addition, they would willingly accept feedback and suggestions for performance improvement. Second, separation would enable the supervisor to make more effort on formative feedback to help teachers improve their teaching skills. In addition, Cleveland et al. (1989) argued that teachers' performance evaluation for summative purposes often involves the comparison among people, while formative evaluation focuses on an individual's strengths and weaknesses.

Other researchers suggested mixing the two roles of summative and formative roles of performance evaluation (Prince \& Lawler, 1986; Dorfman et al., 1986; Boswell \& Boudreau, 2000) found that mixing summative and formative purposes in one meeting was not harmful to teachers' development. In these studies, the more formative assessment was used in teachers' performance evaluation, the better outcomes were achieved in terms of satisfaction and professional development.

The approach adopted in the study will be both prescriptive and collaborative. There is a numerical aspect which entitles supervisors to provide instructors with feedback on their performance. The scale ranges from "not demonstrated to outstanding. It also includes a place for comments, points of strength and action points. According to the observation guidelines, there is a pre-observation discussion to allow instructors to discuss teaching and learning. There is also a post- observation discussion where thoughtful questions are raised to encourage instructors to reflect upon their teaching practices. According to Wallace (1991), prescription has its function which includes authority of experience, but in a warm and pleasant manner. However, the goal is increased collaboration meant to improve the affective 
relationship between the supervisor and the teacher to help teachers foster reflective practice and professional development.

\section{Traditional and New Role of Supervisors}

There are two roles that can be played by supervisors. The first one can be claimed to be traditional related to evaluating teachers' performance, while the second is mainly meant at improving the teaching quality. Sheal (1989) stated that the traditional approach of classroom observation aimed at evaluating the teacher's performance. In this approach, supervisors used to observe the teacher and then provide him/her with feedback of judgment without having the idea of improving the quality of teaching in mind. In this situation, the supervisor, sitting at the back of the class, would observe the performance of an anxious teacher who is trying his best to satisfy the supervisor (Akbari, Gaffar, \& Tajik, 2006). During the observation process, the supervisor used a checklist to decide whether the teacher's methodology was appropriate or not. After observation, the supervisor used to highlight some comments on the teacher's methodology. The teacher, in turn, tried to defend himself/herself, stating that he would try to avoid the drawbacks raised by the supervisor (Akbari et al., 2006).

It can be seen clear that the stages discussed are decided by the supervisor, while the teacher has role of defense. In such a situation, the observation of a teacher's performance does not contribute to the teacher's professional development.

On the other hand, new roles of supervisors emerged in response to the traditional ones. These include planning for and observing the teacher's performance without having in mind a judgmental role. In this regard, the main goal of observing the teaching process is not to judge teaching, but to identify both aspects of strength and action points. In this case, observation aims at improving teachers' performance (Stroller, 1996). In this direction, English language institutes with experienced supervisors usually have successful teachers (Edmonds, 1979), because the supervisor plays a significant role in developing teacher's attitude, creativity and decision-making (Cogan (1973). According to (Moradi, Sepehrifar, \& Khadiv, 2014), cooperation is important between supervisors and teachers as it contributes to the teachers' performance because both the supervisor and the teacher listen to each other and decide together how to take further action for the purpose of improving the teaching quality in various aspects related to teaching.

Farea (2013) maintained that supervisors play a key role in teachers' professional development. Their main task should rely heavily on improving teachers' performance. In this sense, supervisors can play various roles when observing teachers. A supervisor can be a resource of experience, an adviser, and feedback provider and an assessor (Gujjar, Ramzan, \& Bajwa, 2011). Acheson \& Gall (1997) introduced other various roles for supervisors. These may include being a mentor, counselor, a coach, a cooperating teacher, an inspector and a leader. In addition, Koç (2008) describes the supervisor's roles as follows: he cooperates with the teacher to design the course outline and lesson plan; observes the teacher's performance and provides him/her with comments to reflect upon; assists the teacher to put his/her teaching knowledge into practice; conducts scheduled meetings with teachers to discuss teaching methodologies; and exchanges ideas and expertise with teachers regarding their professional development.

\section{E. Problem Statement and Objective}

Based on the researcher's professional contact with EFL instructors as a supervisor and teacher trainer, it has been noticed that they view classroom observation as a dreadful action meant to evaluate their performance in order to either hire or fire them. It is either to keep them in an institution or to terminate their contract. They see the supervisor as an authority whose main role is to judge their teaching performance, and that they act as defenders of their teaching practices. Few of them perceive it as a process that can be implemented for the purpose of identifying their needs in order to support them in their professional career. In addition, it might be claimed that it is easy to criticize teachers' performance and hunt for their mistakes rather than being supportive. The new vision Taif University English Language Center is trying to enhance is that classroom observation is meant to appreciate teachers' performance; it means that what teachers do is important; and it is an opportunity for them to reflect upon their teaching practices for further action of professional development.

\section{F. Research Questions}

This paper seeks to answer the following questions:

1- What is the present level of instructors' performance?

2- What are the instructors' points of strength?

3- What are the instructors' points of weakness/ action points as a base for their needs?

\section{G. Significance of the Study}

The results of this paper will be important to:

- EFL instructors to reflect on their teaching performance in terms of their points of strength in order to transfer these to other colleagues, and to reflect on their action points that will form a base for their professional development.

- The Quality Assurance and Professional Development Unit in the English language Center to consider the instructors' points of strength and action points for further action of professional development. Points of strength can be 
transferred to other colleagues as success stories, and action points will be the starting point for further training workshops on teachers' professional development.

- EFL scholars to consider the study recommendations for further related research.

\section{REVIEW OF RELATED STUdIES}

To the best of the researcher's knowledge, few studies have been conducted recently to investigate the evaluation of teachers' performance. However, there are studies related to the evaluation of performance in general. The most recent and relevant study was conducted by Kocak (2000) who investigated the evaluation process in the Turkish educational system. He pointed out that the results of the studies related to the evaluation process revealed that inspector-focused evaluation systems are not objective, reliable, or functional. According to him, there is a need for a system of teacher evaluation which is functional, transparent, and objective in order to develop the teaching quality system in Turkey. To achieve this purpose, he developed a teacher performance evaluation. The results showed that the scale of teachers' performance evaluation developed was valid and reliable in measuring teachers' performances.

Another relevant study on teachers' performance evaluation was conducted by Milanowski (2006) who studied the idea of splitting the roles of summative and formative performance evaluation. He pointed out that research papers on performance evaluation have argued that separating the two roles of summative and formative evaluation will bring about staff that is less defensive. They would be more open to discussing performance problems and accepting suggestions regarding their performance. Thus, evaluators will be able to provide more assistance toward improving performance. In his study on newly recruited teachers, he assigned them to two groups. The first group includes a split role where formative evaluation was provided by a peer mentor, and summative evaluation by managers and peer evaluators. The second group involves a combined role where formative evaluation and summative evaluation were provided by a peer. Teachers' responses were assessed using interviews, a survey, and performance ratings. The results revealed that there were no major differences between the groups in terms of teachers' openness to discussing the difficulties, accepting feedback, and the significance of performance development. These results have the implication of focusing on developmental assistance regardless the idea of splitting the roles of formative and summative evaluation.

Another study was conducted by Taylor \& Tylor (2011) who studied the effect of evaluation on employee performance. He stated that employees can invest in evaluation for their development. They found that evaluation based on classroom evaluation and performance standards can improve teachers' performance during evaluation and future endeavors of teachers' professional career.

\section{METHOD}

In this part, the researcher describes the procedures of data collection and analysis. It describes how the population and sample of the study were identified; how the study instrument was validated and checked for reliability; and the procedures followed for conducting the study and analyzing the data.

\section{A. Population and Sample Selection}

The population of the study consisted of ninety-five EFL instructors teaching English in the English Language Center at Taif University in the first semester of the academic year 2019-2010. Sixty- nine instructors were observed to achieve the study purposes.

\section{B. Study Instrument}

The researcher developed the observation checklist after reviewing related literature to find a tool to be used for identifying the EFL instructors' level of performance. The checklist includes a scale of four descriptive criteria $(1=$ not demonstrated, $2=$ needs improvement, $3=$ satisfactory, $4=$ outstanding. There is also a place for observers to write their comments for each domain. At the end of the checklist, observers add their remarks on the instructors' points of strength and action points for further action of analysis and professional development. (Appendix A)

\section{Instrument Validity and Reliability}

In order to check the validity of the observation checklist, six EFL specialists were kindly requested to check if the domains and description of each domain were appropriate and relevant to the context. To check the instrument reliability, Cronbach alpha was used for this purpose. It was found 0.87 , which is convenient.

\section{Study Procedures}

The researcher requested the approval of the English Language Center director to conduct the study. The director held a meeting with the supervisors who were assigned the task of observing the instructors' performance to discuss the observation guidelines with them and receive their feedback so that there is consensus on the guidelines that will direct the observation process. The observation checklist was checked for validity and reliability. Having the consent of the instructors, the observation process was carried out. At the end of process, the researcher collected the observation checklist and processed the results using the appropriate statistical methods. Based on the study findings, the researcher came into a number of conclusions and recommendations. 


\section{E. Statistical Analysis}

In order to answer the first question addressing the instructors' level of performance, the researcher used descriptive statistical analysis including the use of means, standard deviation and percentages. Content analysis was used to answer the second and third questions which aimed to identify the instructors' points of strength and action points for further professional development.

\section{RESUlTS AND DiscuSSION}

To answer the first question addressing the instructors' present level of performance, Table 1 shows means, standard deviation and percentages of their performance.
Key: $1=$ Not demonstrated
$2=$ Needs improvement
$3=$ Satisfactory
$4=$ Outstanding

TABLE 1.

\begin{tabular}{|c|c|c|c|c|c|c|c|}
\hline \multicolumn{8}{|c|}{ MEANS, STANDARD DEVIATION AND PERCENTAGES OF INSTRUCTORS' PERFORMANCE } \\
\hline \multirow{2}{*}{ No. } & \multirow{2}{*}{ Criteria } & \multirow{2}{*}{ Mean } & \multirow{2}{*}{$\begin{array}{c}\text { Std. } \\
\text { Deviation }\end{array}$} & \multicolumn{4}{|c|}{ Percentages } \\
\hline & & & & 1 & 2 & 3 & 4 \\
\hline 1 & $\begin{array}{l}\text { Subject matter content } \\
\text { shows good command and knowledge of subject matter; } \\
\text { demonstrates breadth and depth of mastery }\end{array}$ & 3.31 & .58 & 0.0 & 5.8 & 56.5 & 37.7 \\
\hline 2 & $\begin{array}{l}\text { Organization } \\
\text { organizes subject matter; evidences preparation; is thorough; } \\
\text { states clear objectives; emphasizes and summarizes main points }\end{array}$ & 2.98 & .71 & 1.4 & 21.7 & 53.6 & 23.2 \\
\hline 3 & $\begin{array}{l}\text { Rapport } \\
\text { holds interest of students; is respectful, fair, and impartial } \\
\text { encouraging; interacts with students, shows enthusiasm }\end{array}$ & 3.30 & .75 & 4.3 & 4.3 & 47.8 & 43.5 \\
\hline 4 & $\begin{array}{l}\text { Teaching methods } \\
\text { uses relevant teaching and assessment methods, techniques, and } \\
\text { technology; includes variety, balance, group involvement; uses } \\
\text { examples that are simple, clear, precise, and appropriate; stays } \\
\text { focused on and meets stated objectives }\end{array}$ & 2.49 & .88 & 11.6 & 42.0 & 31.9 & 14.5 \\
\hline 5 & $\begin{array}{l}\text { Presentation } \\
\text { establishes classroom environment conducive to learning; uses } \\
\text { strong projection, proper enunciation, and standard English }\end{array}$ & 2.98 & .83 & 5.8 & 17.4 & 49.3 & 27.5 \\
\hline 6 & $\begin{array}{l}\text { Management } \\
\text { uses time wisely; attends to course interaction; demonstrates } \\
\text { leadership ability; maintains discipline and control; maintains eye } \\
\text { contact; uses a clear voice }\end{array}$ & 2.53 & .88 & 8.7 & 46.4 & 27.5 & 17.4 \\
\hline 7 & $\begin{array}{l}\text { Sensitivity } \\
\text { exhibits sensitivity to students' personal culture, gender } \\
\text { differences and disabilities, responds appropriately in a non- } \\
\text { threatening, pro-active learning environment }\end{array}$ & 3.27 & .68 & 2.9 & 4.3 & 35.1 & 37.7 \\
\hline 8 & $\begin{array}{l}\text { Assistance to students } \\
\text { assists students with academic problems; uses differentiated } \\
\text { instruction techniques }\end{array}$ & 2.98 & .757 & 2.9 & 20.3 & 52.2 & 24.6 \\
\hline 9 & $\begin{array}{l}\text { Personal } \\
\text { evidences self-confidence; maintains professional comportment } \\
\text { and appearance }\end{array}$ & 3.24 & .60 & 0.0 & 8.7 & 28.0 & 33.3 \\
\hline 10 & $\begin{array}{l}\text { Physical aspects of classroom } \\
\text { states location and physical attributes of classroom, number of } \\
\text { students in attendance, layout of room, distractions if any; list any } \\
\text { observations of how physical aspects affected content delivery }\end{array}$ & 2.82 & .89 & 10.1 & 18.8 & 49.3 & 21.7 \\
\hline
\end{tabular}

It is clear from the the table above that the overall performance of instructors is either satisfactory or outstanding. The means, which are above 2, standard deviation and percentages indicate that the majority of instructors have performed well. This performance can be due to the fact that they have the competencies either from their teaching experience and that they have undertaken professional development courses conducted at the English Language Center. The professional development program has been conducted for five years now in order to develop the instructors' knowledge and skills in various aspects of teaching and learning English as a foreign language. However, the least two domains as shown in the table above are "teaching methods" and "management" which got the means of 2.49 and 2.53 respectively. The means are more than 2 , which indicate that they performed satisfactorily, but having a look at the percentages, it is clear that these two areas still need further consideration. In the area of teaching methods, $53.6 \%$ of the instructors need further professional development. In addition, the percentage of instructors' performance in the domain of management is $55 \%$, which is also an indication that they need to develop their competencies in this area. What comes after these two domains are the areas of organization, presentation, assistance to students, and physical aspects of classroom. In these four areas, the instructors' performance was satisfactory as the means were above 2. However, as the means are less than 3, it can be claimed that some instructors still need to work on these areas for further professional development. This, of course, goes with the idea that professional development is a continuous process where teachers need training while in the teaching profession based on their needs. 
In order to answer the second question related to the instructors' points of strength, Table 2 displays the strengths summarized according to their frequency:

TABLE 2.

FREQUENCY AND PERCENTAGE OF INSTRUCTORS' POINTS OF STRENGTH

\begin{tabular}{|c|l|c|c|}
\hline No. & \multicolumn{1}{|c|}{ Points of strength } & Frequency & Percentage \\
\hline 1 & Motivating learners, which gets them involved & 17 & 47.3 \\
\hline 2 & Giving constructive feedback to learners & 10 & 27.7 \\
\hline 3 & Implementing differentiated instruction effectively & 5 & 13.9 \\
\hline 4 & Showing self-confidence & 4 & 11.1 \\
\hline
\end{tabular}

It is clear from the table above that the instructors observed have displayed certain competencies other than those shown in Table 1, but with different percentages. As stated earlier, the instructors joined a number of professional development sessions on areas related to teaching English as a foreign language, which could have enabled them to be more competent in these areas. The instructors who have displayed these competencies have been requested to run training sessions to cascade these skills to other colleagues. Meanwhile, as some areas received a little percentage, the instructors still need training sessions on these areas based on their professional development needs.

In order to answer the third question addressing the instructors' points of weakness as action points, instructors need to consider for their professional development, Table 3 shows these action points according to their frequency of occurrence.

TABLE 3.

FREQUENCY AND PERCENTAGE OF INSTRUCTORS' POINTS OF WEAKNESS

\begin{tabular}{|c|l|c|c|}
\hline No. & \multicolumn{1}{|c|}{ Points of weakness } & Frequency & Percentage \\
\hline 1 & Classroom management (Time management, student grouping, discipline) & 42 & 55.3 \\
\hline 2 & Teacher-centered- Teacher talk time is too much & 18 & 23.7 \\
\hline 3 & Giving feedback to students on their performance & 13 & 17.1 \\
\hline 4 & No organized way of using the board & 3 & 3.9 \\
\hline
\end{tabular}

It is clear from the table above that many instructors have training needs in issues related to classroom management such as time management, student grouping and discipline. This goes with the results discussed in table one. The most salient need is classroom management. Instructors also have needs in areas related to giving feedback to learners, teacher-centeredness, and effective use of the blackboard. These action points can be seen in terms of needs to be considered in the ongoing process of professional development run at TUELC. In addition, there are two competencies that were shown as points of strength and points weakness in some of the instructors' performance as shown in Tables 2 and 3. This competency is providing learners with feedback. Some instructors were competent in this area, while others still need development. Here lies the importance of sharing experience between instructors in this area of teaching and learning.

\section{CONCLUSIONS AND RECOMMENDATIONS}

The present paper aimed to investigate EFL instructors' performance at university level according to prescriptive and collaborative approaches in supervision. A number of experienced supervisors observed the instructors' performance according to an observation checklist (Appendix A) which has both a numerical section to describe the instructors' performance and provide them with feedback. The checklist has also two sections where the supervisors can observe other points of strength and points of weakness in the instructors' performance. In these two sections, both supervisors and instructors can work collaboratively to discuss relevant teaching issues. It is the stage where the instructors get the opportunity to reflect on their teaching practices. In the observation process, the supervisors followed observation guidelines to maintain the objective of being supportive rather than judgmental while and after observing instructors (Appendix B). The results revealed that the majority of instructors' performance was either satisfactory or outstanding. The instructors also displayed that they are competent in other areas discussed in Table 2.However, there are other areas of professional development shown in Tables 3 where instructors need to work on to develop their teaching competencies. The Quality Assurance and Development Unit in the English Language Center is recommended to consider the instructors' points of strength to cascade training to other instructors. It is also recommended that more professional development sessions be conducted on action points revealed during the observation process.

Implications for future research

The results of this study have implications for the Quality Assurance and Development Unit in the English Language Center and EFL practitioners. The research is timely in the sense that it would be helpful for the Quality and professional Development Unit to conduct more professional development sessions where the supervisors and instructors can further discuss and reflect on issues raised during the observation process. In these sessions, the instructors can share experience and reflect on teaching practices as well. 
Appendix A. English language Centre: Classroom Observation Form

Instructor: Course

Observer(s): Date and Time

\begin{tabular}{|c|c|c|c|c|c|}
\hline Review Section & \multicolumn{4}{|c|}{ Scale } & Description/Comments \\
\hline $\begin{array}{l}\text { Subject matter content } \\
\text { shows good command and knowledge of subject matter; demonstrates breadth and depth of } \\
\text { mastery }\end{array}$ & 1 & 2 & 3 & 4 & \\
\hline $\begin{array}{l}\text { Organization } \\
\text { organizes subject matter; evidences preparation; is thorough; states clear objectives; } \\
\text { emphasizes and summarizes main points }\end{array}$ & 1 & 2 & 3 & 4 & \\
\hline $\begin{array}{l}\text { Rapport } \\
\text { holds interest of students; is respectful, fair, and impartial encouraging; interacts with } \\
\text { students, shows enthusiasm }\end{array}$ & 1 & 2 & 3 & 4 & \\
\hline $\begin{array}{l}\text { Teaching methods } \\
\text { uses relevant teaching and assessment methods, techniques, and technology; includes } \\
\text { variety, balance, group involvement; uses examples that are simple, clear, precise, and } \\
\text { appropriate; stays focused on and meets stated objectives }\end{array}$ & 1 & 2 & 3 & 4 & \\
\hline $\begin{array}{l}\text { Presentation } \\
\text { establishes classroom environment conducive to learning; uses strong projection, proper } \\
\text { enunciation, and standard English }\end{array}$ & 1 & 2 & 3 & 4 & \\
\hline $\begin{array}{l}\text { Management } \\
\text { uses time wisely; attends to course interaction; demonstrates leadership ability; maintains } \\
\text { discipline and control; maintains eye contact; uses a clear voice }\end{array}$ & 1 & 2 & 3 & 4 & \\
\hline $\begin{array}{l}\text { Sensitivity } \\
\text { exhibits sensitivity to students' personal culture, gender differences and disabilities, responds } \\
\text { appropriately in a non-threatening, pro-active learning environment }\end{array}$ & 1 & 2 & 3 & 4 & \\
\hline $\begin{array}{l}\text { Assistance to students } \\
\text { assists students with academic problems; uses differentiated instruction techniques }\end{array}$ & 1 & 2 & 3 & 4 & \\
\hline $\begin{array}{l}\text { Personal } \\
\text { evidences self-confidence; maintains professional comportment and appearance }\end{array}$ & 1 & 2 & 3 & 4 & \\
\hline $\begin{array}{l}\text { Physical aspects of classroom } \\
\text { states location and physical attributes of classroom, number of students in attendance, layout } \\
\text { of room, distractions if any; list any observations of how physical aspects affected content } \\
\text { delivery }\end{array}$ & 1 & 2 & 3 & 4 & \\
\hline
\end{tabular}

Key= $1=$ Not demonstrated $\quad 2=$ Needs improvement $3=$ satisfactory $4=$ Outstanding

\section{APPENDIX B. TEACHERS' PERFORMANCE AND OBSERVATION GUIDELINES}

\section{Introduction}

In response to the instructors' concerns raised when classroom observation is conducted in terms of supervisors' judgmental policy when observing teachers' performance, the researcher developed a set of observation guidelines and discussed them with the supervisors for comments and suggestions. These guidelines help the supervisors to adopt a supportive rather than a judgmental one when implementing the observation process. It consists of rationale, objectives, and guidelines that govern the procedures to be followed by the supervisors. The researcher consulted and adapted a document by Knol (2018) to add to his ideas of the observation guidelines section to be conducted for the purposes of being supportive rather than judgmental.

\section{Rationale}

Classroom observation has been perceived as a dreadful action meant to evaluate teachers' performance in order to either hire or fire them. It is either to keep them in an institution or to terminate their contract. In addition, it might be claimed that it is easy to criticize teachers' performance and hunt for their mistakes rather than being supportive. The new vision Taif University English Language Center is trying to enhance is that observation is meant to appreciate teachers' performance; it means that what teachers do is important; and it is an opportunity for their professional growth.

Objectives

Classroom observation is meant to serve the following purposes:

1- To foster the fact that there is a plenty of opportunity to show teachers' strengths.

2- To appreciate teachers' performance rather than evaluating it.

3- To support teachers rather than criticize them.

4- To encourage teachers to reflect on their teaching practices by asking them relevant questions on what went well and action points need to be considered.

\section{Observation Guidelines}

\section{Make teachers feel valued}

The supervisor contacts the teacher in person to arrange a time to visit his class. He greets him with a smile and expresses his willing to see his class. He mentions that he respects the teacher's work and is excited to see him in action.

\section{2- The Pre-observation Discussion}


The supervisor conducts a pre-observation discussion to help alleviate anxiety and provide the observer with information about what he would like to accomplish on the day of the visit. The collaborative nature of the preobservation dialogue provides an opportunity for the observer and the instructor to reflect upon and discuss teaching and learning and to experience the observation and feedback process as a means to improve teaching rather than simply as a form of evaluation and judgment.

\section{3- Look for learning, not teaching}

The supervisor should focus on the idea that he is observing the learning process instead of observing an instructor teaching a lesson. Here are some questions to help guide the supervisor.

- What do we want students to learn?

- How do we know students are learning?

- What do we do when we find out students are not learning?

\section{Thank teachers publicly}

At the end of the lesson, the supervisor should thank the teacher for the opportunity to spend a period in his classroom. He does this in front of his students.

\section{Follow up quickly and kindly}

The supervisor should follow up quickly with a post-observation discussion to discuss points of strengths and action points, and encourage the instructor to reflect upon their teaching practices.

\section{Show you paid attention}

When the supervisor and the teacher meet to talk about the lesson, the supervisor should have thoughtful follow-up questions. He does not simply read off of his report. Instead, he leads an interesting conversation that enhances teachers' reflection on his teaching practices.

\section{7- Use exploratory language not judgmental}

Using exploratory language when giving teachers feedback helps him discover action points and emphasize the point that the observer is supportive. Instead of asking the teacher: why didn't you explain the aim of the lesson?, the observer can ask: What would be the advantage of explaining the aim of the lesson? Instead of saying: some learners weren't clear what to do for the first task. You need to check your instructions, the observer can say: I saw some students didn't know what to do. What do you think caused this?

\section{ACKNOWLEDGMENTS}

The researcher would like to acknowledge the contribution of the supervisors and instructors who participated in the observation process. Thanks go to the supervisors for their feedback on the observation guidelines. Many thanks go to the EFL specialists for validating the study instrument. Sincere thanks also go to the instructors who were observed.

\section{REFERENCES}

[1] Acheson, K., \& Gall, M. D. (1997). Techniques in the clinical supervision of teachers: preservice and inservice applications (4th ed.). New York: Longman.

[2] Akbari, R., Gaffar, S. R., \& Tajik, L. (2006). Developing a classroom observation model based on Iranian EFL teachers' attitudes. Journal of Faculty of Letters and Humanities, 49 (198), 1-37.

[3] Boswell, W. R. \& Boudreau, J. W. (2000). Employee satisfaction with performance evaluations and evaluators: The role of perceived evaluation use. Human Resource Development Quarterly, 11(3), 283-299.

[4] Cleveland, J. N., Murphy, K. R. \& Williams, R. E. (1989). Multiple uses of performance evaluation: prevalence and correlates. Journal of Applied Psychology, 74(1), 130-135.

[5] Cogan, M. L. (1973). Clinical supervision. Boston: Houghton-Mifflin.

[6] Donaldson, Morgaen. L. (2009). So long, Lake Wobegon? Using teacher evaluation to raise teacher quality. Center for American Progress. Retrieved on April, 15, 2019 from https://www.americanprogress.org/issues/education-k12/reports/2009/06/25/6243/so-long-lake-wobegon/.

[7] Dorfman, P. W., Stephan, W. G. \& Loveland, J. (1986). Performance evaluation behaviors: supervisor perceptions and subordinate reactions. Personnel Psychology, 39 (1), 579-597.

[8] Edmonds, R. R. (1979). Some schools work and more can. Social policy, 9(5), 28-32.

[9] Farea, Q. D. A. (2013). EFL Teachers' perception of the professional role of EFL educational supervisors in Yemeni Secondary Schools. Journal of Education Science, 21(1), 1- 44.

[10] Gujjar, A. A., Ramzan, M., \& Bajwa, M. J. (2011). An evaluation of teaching practice: practicum. Pakistan Journal of Commerce and Social Sciences, 5(2), 302-318.

[11] Hanushek, Eric A., and Steven G. Rivkin. (2010). Using value-added measures of teacher quality. American Economic Review, 100(2): 267-271.

[12] Kocak, R. (2006). The Validity and Reliability of the Teachers' Performance Evaluation Scale, Educational Sciences: Theory\& Practice, 6(3), 799-808.

[13] Knol, J. (2018). Seven things principals can do to make a teacher observation valuable. Retrieved on March, 10, 2019 from https://schoolleadersnow.weareteachers.com/successful-teacher-observation/.

[14] Koç, E. M. (2008). An investigation of cooperating teachers' roles as mentors during the teaching practicum at distance BA program in ELT at Anadolu University Open Education Faculty. Unpublished Ph. D, Anadolu University, Eskişehir. 
[15] Looney, J. (2011). Developing high-quality teachers: teacher evaluation for improvement. European Journal of Education, 46 (4), 440-455.

[16] Milanowski. A. (2006). Split roles in performance evaluation - A field study involving new teachers, J Pers Eval Educ, 18(1), 153-169.

[17] Moradi, K., Sepehrifar, S., \& Khadiv, T. P. (2014). Exploring Iranian EFL teachers' perceptions on supervision. ProcediaSocial and Behavioral Sciences, 98 (1), 1214-1223. http://dx.doi.org/10.1016/j.sbspro.2014.03.536.

[18] Motoko, A., Letendre, G. K. \& Scribner, J. P. (2007). Teacher quality, opportunity gap, and national achievement in 46 countries, Educational Researcher, 36, 369-387.

[19] Nye, B., Konstantopoulos, S. \& Hedges, L. V. (2004). How large are teacher effects? Educational Evaluation and Policy Analysis, 26 (2) 237-257.

[20] OECD. (2009a). Creating Effective Teaching and Learning Environments: First Results from TALIS (Paris, OECD).

[21] Peterson, K. D. (2000). Teacher Evaluation: A Comprehensive Guide to New Directions and Practice. (2 ${ }^{\text {nd }}$ Ed). Thousand Oaks, California: Corwin.

[22] Prince, J. B. \& Lawler E. E. III. (1986). Does salary discussion hurt the developmental performance evaluation? Organizational Behavior and Human Decision Processes, 37, 357-375.

[23] Randall, M. \& Thornton, B. (2001). Advising and Supporting Teachers. Cambridge University Press. Cambridge

[24] Sheal, P. (1989). Classroom observation: training the observers. ELT journal, 43(2), 92-104. http://dx.doi.org/10.1093/elt/43.2.92.

[25] Stoller, F. (1996). Teacher supervision: Moving towards an interactive approach. English Teaching Forum, 34(2), 2-9.

[26] Taylor, Eric S., and John H. Tyler. (2012). The effect of evaluation on teacher performance. American Economic Review, 102 (7): 3628-51.

[27] Wallace, M. J. (1991). Training foreign language teachers: A reflective approach. Cambridge University press. Cambridge

[28] Weisberg, D., Susan S., Jennifer M., \& David K. (2009). The Widget Effect: Our national failure to acknowledge and act on teacher effectiveness. New York City, N.Y.: The New Teacher Project.

[29] Widodo, H. P., \& Zakaria, F. (2008). Language teacher supervision: A case-based approach. Reading, 8(1), 14-43

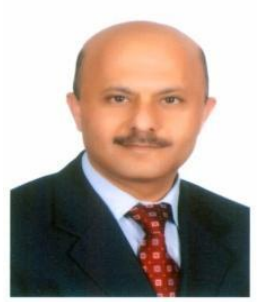

Thaer Issa Tawalbeh was born in the Hashemite Kingdom of Jordan on June, 10, 1968. He got his B.A. in English Language and Literature from Yarmouk University, Jordan in 1986. In 1997, he got his M.A. in TEFL from Yarmouk University. In 2005, he graduated from Amman Arab University for Graduate Studies with a $\mathrm{PhD}$ in TEFL.

His teaching experience ranges from being a teacher of English, a supervisor, the head of foreign languages division in the Jordanian Ministry of Education, and an instructor in the University of Jordan and the Arab Open University in Jordan. He has been the supervisor of the Academic Coordination and Follow up Unit at Taif University English Language Center since 2017. He got "Train the Trainer" Certificate from Cambridge University Press in 2018. He published a number of articles. The latest ones are: Investigating EFL Learners' Multiple Intelligences in the Preparatory Year at Taif University; EFL instructors' perceptions of Blackboard Learning Management System (LMS) at University Level; and - Instructors' Perceptions of English for Academic Purposes Textbooks at University Level.

His research areas focus on teachers' professional development, and curricula development and evaluation. Thaer has participated in a number of international conferences and seminars such as TESOL Arabia and IATEFL and presented papers in conferences. 